\title{
LA EXTRAÑA ORNITOLOGÍA MÍSTICA DE SAN JUAN DE LA CRUZ: LA FILOMENA Y EL PÁJARO SOLITARIO
}

\author{
Luce López-Baralt \\ Universidad de Puerto Rico, Rio Piedras, Puerto Rico. \\ lucelopezbaralt@gmail.com
}

RESUMEN / ABSTRACT

Las extrañas aves místicas de San Juan de la Cruz han dejado perplejos a los lectores porque resultan excéntricas dentro del canon literario europeo. Ello no debe asombrarnos demasiado, sin embargo, pues no es la primera vez que el misterio artístico del Reformador del Carmelo dificulta la intelección cómoda de sus obras. Ya lo advertía Dámaso Alonso: el arte de San Juan es "misterioso como un aerolito". Llevo décadas asediando los enigmas del poeta, y no puedo estar más de acuerdo. En concreto, me ha llamado la atención no solo la simbología mística que San Juan parece compartir en buena medida con los místicos del Islam, a la que he dedicado un libro de propósito (López-Baralt 2000), sino sus alegorías enigmáticas ornitológicas, de las que también me he ocupado en trabajos anteriores (López-Baralt 1985/1989 y 2012a), pero que aquí veo de manera conjunta y exhaustiva. Veamos más de cerca estas aves simbólicas e intentemos interrogar el porqué de su arcano.

Palabras Clave: San Juan de la Cruz, sufismo, simbolismo místico, ornitología mística, pájaro solitario, filomena, bulbul

\section{The Strange Mystic Ornithology of St John of the CRoss: \\ The Philomena and the Solitary Bird}

St. John of the Cross'strange mystical birds have baffled readers for a long time because they seem foreign in the context of the European literary canon. This is not surprising, given the poet's usual artistic mysteries, which make for a difficult reading. Dámaso Alonso warns the reader: St. John's poetry is "mysterious like an aerolite”. After exploring St. John's literary enigmas for decades, it is not difficult to concur with the Spanish critic. I have carried out a comparative study of the mystical symbolism the Spanish poet seems to share with Sufism (see (López-Baralt 2000), and also of his ornithological allegories (see (López-Baralt 1985/1989y 2012), which I explore in depth and actualize here, trying to understand their elusive origins. 
KEYWORDS: St. John of the Cross, Sufism, mystical symbolism, mystical ornithology, solitary bird, Philomena, bulbul.

Recepción: 22/10/2018

Aprobación: 08/11/2018

\section{A. LA FILOMENA-RUISEÑOR}

Parecería que la "dulce filomena" del "Cántico espiritual", que nos hechiza con su canto en la primavera de un jardín ultramundano, constituiría una reescritura más por parte de San Juan en la larga cadena de refactura de temas grecolatinos de la lírica española. Pero San Juan nunca deja de sorprendernos: la "filomena", pese a su célebre nombre griego, se convierte en sus manos en una rara avis que desentona por completo dentro de un contexto literario occidental. En vez de entonar una miserabile carmen al estilo de las Geórgicas virgilianas, el ruiseñor de San Juan canta al éxtasis transformante. Y eso ya no lo anticipan ni Homero, ni Catulo, ni Virgilio, ni la prolongada estirpe de poetas renacentistas que se hizo eco de la melodiosa pero entristecida ave mitológica.

Cumple que enmarquemos el espacio poético en el que la Filomena juancruciana lanza al aire su salmodia extática. Los protagonistas del "Cántico espiritual" -la Esposa y el Esposo- están por dar fin a sus deliquios de amor y, llegado este momento, se disponen a anidar en las "cavernas de la piedra". Para hacer morada en lo alto de los acantilados se deben haber transmutado simbólicamente en aves dotadas de vuelo: "Y luego a las subidas / cavernas de la piedra nos iremos, / que están bien escondidas, / y allí nos entraremos, / y el mosto de granadas gustaremos". . Al aludir a las enigmáticas "cavernas de la piedra" San Juan cita el versículo 2, 14 del Cantar de los cantares: "paloma mía, puesta en las quiebras de la piedra, en las vueltas del caracol, descubre tu vista...". Casi todos los comentadores del epitalamio hacen claro que se trata de los orificios de los acantilados o montañas pétreas -los foraminibus petrae de la Vulgata- donde suelen anidar las palomas.

El "Cántico", muy en la línea del epitalamio que San Juan interpretó desde una óptica mística, celebra un apasionado amor humano que es, a la vez,

\footnotetext{
Cito siempre por la edición de la Obra completa de San Juan que edité en colaboración con Eulogio Pacho, ocd (López-Baralt/Pacho, eds. 1991-2017). Indico las obras del santo por sus abreviaturas usuales.
} 
símbolo de la unión mística. Al momento de sus nupcias transformantes, el Amado, que otrora era un "ciervo vulnerado", ahora se ha trasmutado, como su amada, en paloma. Es que solo adquiriendo esta forma alada podrá anidar con ella en los acantilados pétreos, y celebrar sus bodas ultramundanas. En medio de su jubiloso ágape nupcial, los recién casados anuncian que degustarán una libación celebrativa, "el mosto de granadas". El vino, como supieron San Bernardo y San Buenaventura, y, siglos antes, los contemplativos del Islam, suele representar la embriaguez extática en el contexto de un poema místico. Pero el mosto de la granada les fue particularmente significativo a los sufíes medievales como Ibn al- 'Arabī o Qašānī (Bakhtiar 8) y San Juan, muy cerca de ellos, advierte cómo bajo la aparente multiplicidad de los granos de la fruta subyace la absoluta unidad de Dios, representada por la bebida embriagante (CB 37, 8).

No le extrañe al lector que los enamorados liben con un simbólico vino islamizante en su noche de bodas sobrenatural: es que San Juan de la Cruz, como he explorado en estudios previos ${ }^{2}$, comparte con los sufíes del medioevo muchos de sus símbolos y de su lenguaje técnico místico más importante. Estamos ante el fenómeno de una literatura europea con numerosas claves literarias árabes, incluso, persas. Los poetas sufíes respetaron un número de equivalencias fijas en su poesía à clef: se trata del lenguaje secreto o trobar clus de cuya clave participaban, según críticos como Louis Massignon (1975) y Émile Dermenghem (1932), exclusivamente los iniciados sufíes. Oigamos lo que Ibn al-Fārị̣ (62-63) ${ }^{3}$ dejó dicho sobre el asunto en el siglo XIII:

Los místicos [...] han acordado expresar con metáforas sus estados espirituales, $[y]$ han organizado un lenguaje que no comprenden quienes no hayan tenido su propia experiencia espiritual, de suerte que [sólo ellos] habrán de comprender el sentido oculto de sus términos, [que] le resultará oculto a quienes no participen [de su clave]. Algunos iniciados expresan diferentes grados de la contemplación mística por los símbolos de los rizos de cabellos, [...], vino, llamas, etc., que a los

\footnotetext{
2 Refiero al lector a mis estudios citados en la Bibliografía.

3 Las traducciones al español del inglés, francés y árabe son mías, aun a pesar de que algunas traducciones españolas de las obras citadas han ido viendo la luz en los últimos años. Advierto también que me sirvo del sistema de transliteración de la Escuela de Estudios Árabes de Madrid, que usó la revista Al-Andalus y ahora la revista Al-Qantara. Con todo, respeto siempre el sistema de transliteración que los distintos estudiosos usan: de ahí las posibles variantes.
} 
ojos de los profanos no constituyen sino una poesía de una apariencia brillante. [Pero] el rizo de cabello [significa] la multiplicidad de cosas que ocultan la faz del Amado; [...] el vino representa [...] la embriaguez espiritual; la llama la irradiación de luz divina en el corazón del que sigue la vía mística...

Esta literatura en clave es antiquísima y constituye una tradición literaria por lo menos desde el siglo x: 'Atțār se jacta de dicho lenguaje hermético, cuya clave secreta sólo los sufíes iniciados conocían ('Ațtār 237-238). Los islamólogos insisten a su vez en este "vocabulario especial": " las gacelas u odas [...] son, para quienes conozcan la clave de su imaginería simbólica, las expresiones fervientes de los corazones [...] embriagados de amor espiritual", explica Margaret Smith (45), subrayando el sentido místico bajo la metaforización erótica. "Pero, a medida que pasa el tiempo, algunas palabras comenzaron a tener un sentido que [los iniciados] podían reconocer". Florence Lederer (1969) tiene razón: el trobar clus termina por lexicalizarse y deviene una convención literaria fácilmente reconocible. Pero reconocible-recordémoslodentro del Islam. De ahí que nos asombra sorprender esta misma imaginería simbólica en las páginas de San Juan.

Damos por descontado, con Carl Jung, Evelyn Underhill y Mircea Eliade, que hay que tomar en cuenta la insistencia de todas las religiones en ciertos símbolos fundamentales: la luz, el fuego, la oscuridad, por no hablar de la deuda neoplatónica en común que tienen los contemplativos cristianos y los sufíes. Pero el caso de San Juan no se puede delimitar a estas coincidencias generales: parecería, como anticipé, que el poeta conoce con demasiada especificidad algunos de los símbolos islámicos más importantes (símbolos que por cierto explora con pormenor Javad Nurbakhsh 1983-1991), como para tratarse de una coincidencia "casual". Incluso en algunos casos en los que el símbolo estudiado pudiera ser patrimonio de la mística universal, la manera particular que tiene San Juan de elaborar dichas imágenes coincide estrechamente con la de los sufíes. Pese a las variantes esperables, he podido documentar más de treinta de estos símbolos compartidos.

Acaso la Madre Ana de Jesús, destinataria del "Cántico espiritual", sabría algo de estos mostos divinales de la Unidad de Dios exprimidos de los rubíes de la granada mística: sospecho que la cultura conventual dentro de la cual se movía el Reformador y sus lectores pudiera haber conservado memoria de estos antiguos símiles espirituales, cuyo remoto origen sufí probablemente no recordarán ya. Pero sí asumirían la equivalencia simbólica 
obligada: como veremos en seguida, la "filomena" constituye un hito más en esta curiosa manera de sugerir a los lectores monacales los misterios del éxtasis transformante. Estos lectores pioneros de seguro sabrían algo y aun harto de estas equivalencias cuya decodificación implica para nosotros tanto esfuerzo erudito.

Cumple que volvamos al "Cántico". La celebración nupcial se sigue desenvolviendo en lo más escondido de las cavernas de la piedra, el espacio de la unión transformante, donde los protagonistas han anidado, y allí es donde escucharemos cantar el canto jubiloso de la "dulce filomena".

La esposa del "Cántico" nos ofrece más detalles de su connubio sagrado. Tras haber libado juntos un extraño licor trascendido, la Esposa celebra el regalo nupcial indecible que a continuación su Amado habrá de ofrecerle:

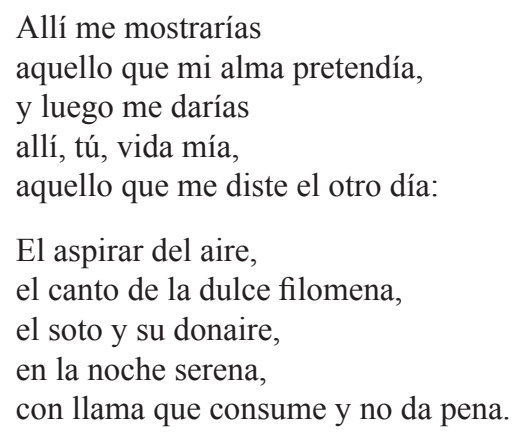

La emisora de los versos emplea el habla azucarada propia de una recién casada, y deja entrever la intimidad con la que se comunica con su Esposo, que apostrofa llamándole "vida mía". En estos momentos culminantes de las nupcias místicas, el lenguaje se amartela cada vez más y nos permite intuir que el matrimonio espiritual ha sido felizmente consumado, o que está en proceso de consumarse.

Salta a la vista, de otra parte, que el deíctico con el cual el poeta indica el espacio indescriptible donde ocurre el misterio del Unus/ambo se duplica con especial ansiedad -"allí", "allí"- lanzándonos a las "cavernas de la piedra" nupciales, que representan en este momento el locus de la manifestación divina. Al poeta le es imposible explicar, sin embargo, en qué consiste el regalo de bodas celestial, pero lo sugiere ahora bajo el afásico pero elocuente "aquello", "aquello", que vuelve a duplicar con desesperación emocional. El concepto del tiempo, por otra parte, se obnubila, pues la temporalidad zigzaguea indecisa entre tiempos indeterminados ("pretendía"; "daría"; 
"me diste el otro día") y con ello San Juan nos indica que nos encontramos al margen de la tiranía sucesiva del discurrir temporal. Estamos asistiendo, recordémoslo, a bodas trascendidas.

El don nupcial que la protagonista pasa a celebrar a continuación es de tal magnitud que no tiene manera de decirlo, y recurre, en su afasia, a una eclosión simbólica de frases nominales sin aparente concatenación secuencial lógica: "el aspirar del aire, / el canto de la dulce filomena...". Las imágenes hiladas carecen también de verbo: San Juan aclimata aquí una vez más la sintaxis del Cantar de los cantares, ya que la lengua hebrea (como la árabe) suelen omitir el verbo "ser", y por ello mismo los versos vertiginosos evocan la anhelante cascada verbal con la que la protagonista poética había dado la bienvenida sobrecogida a su Amado: "Mi Amado las montañas/ los valles solitarios nemorosos / las ínsulas extrañas, / los ríos sonorosos, / el silbo de los aires amorosos". Estamos ante "dislates" místicos, pero justamente por su exuberencia desbordada algo logran sugerirnos del misterio insondable de la unión mística.

Veamos los "dones" sobrenaturales que la amada recibe, porque entre ellos hemos encontrado al fin "el canto de la dulce filomena" que venimos asediando. Los versos parecerían volatilizarse, con su mención pura de aires, cantos, donaires, noches y llamas: el poeta nos coloca al margen del cuerpo y del espacio-tiempo en su inimaginable noche de bodas. El primer regalo nupcial, "el aspirar del aire", no ofrece mucho problema desde cualquier tradición espiritual que quisiéramos comprenderlo, pues en todas se asocia con la alta noticia de Dios. Como se sabe, la "aspiración" -el pneuma de los griegos, la prana de los hindúes, el ruah de los hebreos, el ruh de los árabes- está relacionada tanto con el aliento creador del Génesis, como con el Espíritu Santo o Dios trino osculante y aun con el intercambio de alientos -el beso- con el que los miembros de la pareja se truecan sus almas en las tradiciones literarias neoplatonizantes más diversas.

Hollamos pues un jardín sobrenatural -el del alma en éxtasis-oreado por el aire vivificador de una primavera trascendente. Sabemos que ha llegado la estación florida porque a renglón seguido escuchamos el jubiloso "canto de la dulce Filomena", es decir, del ruiseñor, que el propio poeta asocia a la llegada de "la primavera, pasados ya los fríos, lluvias y variedades del invierno" (CB 39, 8-9). Al fin nos ha sido dado escuchar al ruiseñor sanjuanístico, pero la melodía primaveral que canta es inesperada. Su melodía jubilosa resulta, como adelanté, harto enigmática para un frecuentador de las páginas de Virgilio, de Horacio, de Ovidio, de Marcial, incluso de los más modernos 
Garcilaso, Boscán, Camões, Keats y Heine. Es que todos estos poetas, medulares en la tradición literaria occidental, suelen asociar al ruiseñor con el llanto desconsolado de la pena humana, y no con la alegría desbordante del éxtasis unitivo.

El antiguo mito que reelaboran los citados poetas europeos tiene como protagonista a la ateniense Filomena, que llora su desgracia metamorfoseada en ruiseñor. Su cuñado, el rey Tereo de Tracia, la había violado y le había cortado la lengua para que no informara lo sucedido a su hermana Procne. Filomena borda en una tela el mensaje del suceso, y trama junto a Procne una atroz venganza. Dan muerte al niño Itis, hijo de Tereo y de Procne, y se lo dan como manjar a Tereo. Una vez el rey consume el escalofriante banquete, le muestran la cabeza de la criatura. Al darse cuenta de que se ha comido a su propio vástago, Tereo persigue a las hermanas hasta Daulia, en la Fócide, pero ambas ruegan a los dioses que las conviertan en aves: Procne es metamorfoseada en ruiseñor y Filomena en golondrina en la versión de la leyenda en las fuentes griegas más antiguas. No es hasta que el mito cae en manos latinas que se invierten las dos primeras metamorfosis, y Filomena pasa a ser el célebre ruiseñor que Europa habría de heredar como legado literario asociado al llanto y a la queja.

Virgilio ofrece en sus Geórgicas (IV, 511-515; Virgilio 191) una variante poética al mito y contribuye a forjar la figura del ruiseñor como figuración de la madre desventurada. Sus famosísimos versos cristalizan el motivo temático de la afligida Filomena-ruiseñor que lamenta ahora el robo de sus hijos implumes, que el duro labrador le hurtó del nido. Posada sobre una rama, da rienda suelta a su canto - miserabile carmen-inundando de dolor los espacios circundantes:'Qualis populea maerens Philomela sub umbris / amissos queritur fetus quos duras arator /observans nido implumes detraxit: at illa/ flet noctem, remoque sedens miserabile carmen /integrat, et maestis late loca questibus implet".

Fiel a esta lección magisterial de los clásicos es el "rosignol che si soave piagne" de Petrarca y la "Philomela" que "chora" de Camoens. Pero probablemente la reescritura más hermosa en lengua española del Leitmotiv del ruiseñor quejoso se debe a la pluma de Garcilaso, que usurpa la melancólica ave a Virgilio en su “Égloga 1". Pero Garcilaso no está solo en su recreación de este tópico de la tradición clásica, pues Boscán se le había adelantado en la "Historia de Leandro y Hero". Pero ambos poetas son tan solo los heraldos de un motivo simbólico que habrá de ser obligado en las letras españolas de los siglos áureos: para Francisco de la Torre, "Filomena dulcísima cantando 
/ ensordece la selva con querellas"; mientras que Góngora se solidariza con el "ruiseñor viudo" ante el nido desacralizado. Lope de Vega, por su parte, se vuelve a hacer eco del ave lacrimosa, que empareja ahora con la tórtola en su Arcadia (IV): "Lamenta Filomena, / gime la tortolilla enamorada". Estamos pues ante un ave literaria que, ya como joven violada o como madre desposeída, resulta la encarnación misma del dolor. ¿Qué tiene que ver San Juan de la Cruz con toda esta venerable, tristísima tradición, si su simbólico nido de amor en lo alto de las cavernas de la piedra constituye un tálamo de amor sublime? Parecería que el santo poeta se burla de Virgilio y de sus imitadores al convertir su miserabile carmen en alborozado cántico extático.

Ni siquiera la reescritura pía del ruiseñor que llevan a cabo los contemplativos españoles suaviza el aparente "desmán" literario del Reformador. Malón de Chaire, entre otros, se hace eco del lamento virgiliano en su Conversión de la Magdalena, entreverándolo de ecos garcilasianos: "y el dulce ruiseñor del nido amado/ al aire con querellas le rompiere...". A pesar del nuevo contexto literario sagrado, la filomena sigue representando el dolor de la desposesión. Bernardino de Laredo, por su parte, alude al ruiseñor en su Subida del Monte Sión, que es despreciado por su plumaje castaño y su apariencia humilde. Con todo, alcanza la cima del árbol y canta sin cesar como el contemplativo que, vestido con la capa carmelita de la humildad, mora en lo alto del árbol de la Pasión para orar allí noche y día.

¿De dónde entonces la impertérrita alegría de la filomena sanjuanística? Lo supo bien Jorge Luis Borges, a cuya sabiduría literaria no escapó el hecho de que más de una tradición ha nutrido al ruiseñor literario que tanto ha acompañado a la humanidad con su dulce canto. Los versos de su oda "Al ruiseñor", de La rosa profunda nos aleccionan aquí mejor que los ensayos eruditos de ningún estudioso: “¿En qué noche secreta de Inglaterra/ O del constante Rhin incalculable /Perdida entre las noches de mis noches, /A mi ignorante oído habrá llegado / Tu voz cargada de mitologías, /Ruiseñor de Virgilio y de los persas?"

El maestro argentino, que tanto sabía acerca de la literatura mística musulmana ${ }^{4}$, lleva harta razón en evocar al ruiseñor de Occidente y de Oriente como ave dicotómica. Se trata, en efecto, de dos aves diametralmente opuestas en su dimensión de símbolo literario. Ya recordamos el caso de Virgilio y de sus epígonos europeos, pero enseguida veremos que muchos sufíes ilustres 
se sirvieron a su vez del símil del ruiseñor, ave venerable en el Islam: Aḥmad Gazzālī, Ruzbihān Baqlī, 'Atțār y, sobre todo, Ŷalāl al-dīn Rūmī. El ruiseñor de estos musulmanes (que escriben sobre todo en lengua persa, pero también en árabe, en turco y en urdu) ya no se lamenta, como el de las Geórgicas, sino que celebra exaltado la unión transformante. He aquí que hemos topado al fin con la "dulce Filomena" de San Juan de la Cruz, que conserva el ropaje exterior onomástico de la mitología clásica pero que se comporta como un ave persa. Ajena al desgarramiento desolado de sus antepasados europeos, la avecica soleada de San Juan celebra con sus contrapartidas agarenas la embriaguez del éxtasis transformante. Curioso admitir que un lector musulmán entendería el canto de la filomena juancruciana mejor que un occidental: de ahí mi sospecha de que estas antiguas equivalencias simbólicas aun pudiesen haber sido moneda común literaria en el ambiente de claustro religioso donde San Juan fraguó su arte inmortal, todavía tan incomprendido.

Pero importa que prestemos ahora oído atento al gorjeo trascendente del ruiseñor de los sufíes, que canta sin palabras la presencia indecible de Dios. Es un canto, insiste Annemarie Schimmel, de decodificación automática para los lectores de la poesía mística persa: "[el ruiseñor de la poesía persa] es el pájaro del amor embriagado [...] Cualquiera que haya leído la poesía persa, incluso en traducción, sabe bien del ruiseñor nostálgico por la rosa [símbolo de la Presencia Divina] representa, en clave mística, al alma que ansía la Belleza divina"(Schimmel, Mystical Dimensions 307).

Volvamos a entrar en el deleitoso jardín literario de los persas en busca de la melodía del ruiseñor o bolbol místico. A partir de los siglos once y doce, y aleccionados por los tratados de aves místicas simbólicas como el Risālat al-țayr o Tratado de los pájaros de Abū Ḥamīd Gazzālī y el Mantiq uț-tayr (El lenguaje de los pájaros) de Fariduddīn Aț̣ār, ambos del siglo XII, los poetas contemplativos del Irán llenan de ruiseñores sus huertos extáticos. Estas epopeyas ornitológicas las había inaugurado Abū'Alī al-Ḥusaīn Ibn 'Abdallāh lbn Sīnā o Avicena (980-1037), con su Risālat al-țayr o Discurso del pájaro, escrito originalmente en árabe, pero vertido al persa y comentado profusamente en ambas lenguas. Estas obras pioneras dieron pie a una poesía de aves que servían de heraldos al éxtasis y fue tan consistente que el gran perito en misticismo persa, Henry Corbin, denomina el conjunto literario como el "cycle de l'oiseau".

Estos textos persas que inauguran el símil de las aves contemplativas establecen ya en firme la noción de que el "lenguaje de los pájaros" es el lenguaje de los místicos. El Leitmotiv es coránico en última instancia, ya que 
Salomón celebra haber recibido este lenguaje inefable de Dios en el Corán (XXVII, 16): “¡Hombres!” Se nos ha enseñado en lenguaje de los pájaros y se nos ha dado toda clase de cosas. Esto es un favor manifiesto". El persa Naŷm ad-dīn al-Kubrā admite que él también ha sido bendecido con este lenguaje sin par: "La alabanza a Dios, que nos dio el lenguaje de los pájaros".

Pero entre todas las aves del jardín extático oriental, el ruiseñor se lleva la palma. En su Dīwān-i kābir ya Kulliyāt-i Shams, Ŷalāl al-dīn Rūmī invita al ruiseñor o bolbol a que acuda al púlpito de la rama para ofrecer un sermón acerca de la belleza de Dios. Es que el ruiseñor de los persas, como nos recuerda una vez más Annemarie Schimmel, "también es el director de los músicos", que a su vez se puede asociar con la bolbola, "la botella de cuello largo que hace un sonido muy agradable cuando escancia el vino durante las fiestas regocijadas de la primavera". Coincidiendo de cerca con Rumi, canta Rūzbehān Baqlī: "Cuando el ruiseñor [del espíritu] se embriaga con la rosa, escuchará con el oído del corazón [la canción de su Amado] en la fuente de la preeternidad". En su Diván al Sol de Tabriz, Rūmī insiste en el significado místico del canto del bolbol: "De ahora en adelante el ruiseñor del jardín entonará nuestra canción: cantará acerca del Amor, que imparte el azúcar y que hace florecer el espíritu". En su citado Dīwān-i kābir, el poeta celebra la superioridad del conocimiento místico infuso por sobre la aridez de la teología racional. Salta a la vista que el dichosísimo bolbol de los místicos del Irán va guardando más relación con el ruiseñor juancruciano que la malaventurada "filomena" de la tradición clásica, que nunca entonó estas indecibles cantinelas supraterrenales.

Pero el Reformador orientaliza aún más a su dulcísima filomena. El verso que sigue a su prodigioso canto es muy extraño: "el soto y su donaire". La aplicación de la noción de "donaire" o "gracia" a un soto o bosque de árboles es inaudita. En nuestra lengua el adjetivo "donaire" se suele aplicar a personas con gracia, y el soto sanjuanístico parecería moverse con dicha gracia. Por más, parecería haber adquirido su "donaire" al eco del canto de la filomena, que precede su misterioso movimiento danzante. La lírica europea no nos ayuda a comprender estas imágenes, aparentemente inconexas, pero la intertextualidad literaria islámica nos permite en cambio ver que los símiles sanjuanísticos están más concatenados de lo que parecería a primera vista. Schimmel nos da la clave cuando comenta los versos en los que Rūmī alude al aire primaveral que orea el jardín de su alma. El ruiseñor canta y su música sin palabras hace bailar de júbilo el bosque, porque ha quedado invitado a unirse a la danza cósmica en celebración de Dios: 
La creación se asemeja a una gran danza cósmica en la que la naturaleza, adormecida en la no-existencia, escucha de repente el llamado divino y acude presurosa a la existencia en una danza extática. Los árboles, las flores y los jardines que han asumido la existencia continúan danzando [...] tocados por la brisa primaveral, escuchando las melodías del ruiseñor [...] El ruiseñor regresa de su viaje y convoca a los habitantes del jardín a acompañarlo en el sama para celebrar la primavera [...] las hojas, vestidas de verde como las huríes, danzan alegres en la tumba de enero [...] Solo las ramas secas no se mueven al son de esta brisa y de esta maravillosa melodía, y son comparables a los pechos secos de los eruditos y de los filósofos. (Schimmel, The Triumphal Sun 220-221)

Parecería que Annemarie Schimmel describe el verso del "Cántico" que nos ocupa - "el soto y su donaire"- ya que insiste en otro lugar: "asimismo los árboles danzan en la brisa primaveral" (Schimmel, The Triumphal Sun 116). No es de extrañar, pues hace años la docta investigadora me confesó que no se asombraba de los misterios sanjuanísticos que tanto había "asustado" a Marcelino Menéndez Pelayo y a Dámaso Alonso porque solía leer a San Juan "como si fuera un sufi". A un lector asiduo de Rūmī, no cabe duda, no le puede parecer incongruente que el soto baile al son de la melodía primaveral del ruiseñor. Escuchemos una vez más los versos del Matnawī de Ŷalāl al-dīn Rūmī:

¡Oh viento, haz danzar a las ramas en recordación del momento en que nos hiciste intuir la unión!

¡ Mira estos árboles, todos irisados de alegría en reunión de beatitud!

[...]

¡Ven al jardín infinito del corazón y [...] observa sus retoños verdes, cómo danzan $[\ldots]$

Ha llegado la primavera al vergel bienaventurado de los poetas sufíes, donde canta el ruiseñor. Ya sabemos que también San Juan insufló de súbito la estación florida dentro del "Cántico", porque explica que su filomena inauguraba su canto justamente porque ya había pasado el invierno. En los comentarios en prosa, el poeta elabora toda una teoría teológico-mística en tomo al significado de esta súbita primavera espiritual:

... así como el canto de filomena, que es el ruiseñor, se oye en la primavera, pasados ya los fríos, lluvias y variedades del invierno, 
y hace melodía al oído y al espíritu recreación, así en esta [...] transformación de amor que tiene ya la Esposa en esta vida, amparada ya y libre de todas las turbaciones [...] temporales, y [...] purgada de las imperfecciones, penalidades y nieblas, así del sentido como del espíritu, siente nueva primavera en [...] anchura y alegría de espíritu. (CB 39, 8)

Ya no nos puede extrañar que el santo coincida casi al pie de la letra con los espirituales del Islam en lo que se refiere a la teoría mística detrás de este resurgimiento primaveral del jardín florido al que acude el ruiseñor a musicalizar la transformación en Dios. Los inviernos en las estepas de Anatolia pueden ser largos y muy fríos, y todos celebran con júbilo el advenimiento de la primavera, pero sobre todo nuestro tantas veces citado Mawlāna Rūmī, para quien la vuelta de las estaciones tiene, como para San Juan, un hondo sentido trascendente. El invierno es el momento de practicar la paciencia espiritual, a la manera de los árboles, que guardan celosamente su savia para hacerla circular en el momento preciso, cuando el sol acaricia sus ramas y las viste de verde, como los bienaventurados del paraíso islámico. El invierno, como nos recuerda una vez más Annemarie Schimmel, es el momento en el que el contemplativo se repliega sobre sí mismo para acumular fortaleza espiritual y para limpiarse de toda atadura material indebida. Los tesoros espirituales secretos que Dios les ha concedido a sus siervos en soledad solo podrán manifestarse en el momento preciso: en la primavera de sus almas, que es a manera de resurrección mística simbólica. Durante los fríos invernales de la purgación, de la sequedad y del repliegue espiritual, el ruiseñor ha desaparecido del jardín helado. Cuando el hielo se derrite, ceden las ataduras que lo aprisionaban, tanto materiales como espirituales, y por eso Rūmī celebra en su Fīhi mā fìhi: "En completa aniquilación espiritual exclamé: 'Oh Rey de reyes, / todas las imágenes se han derretido en este fuego!'” (Los sufíes, como San Juan, despreciaban estas ataduras espirituales al mundo de las imágenes, ya que Dios no tiene imagen). Es pues, tras quedara salvo de toda perturbación y atadura imperfecta cuando el avecilla canora puede regresar triunfante a sembrar su canto extático en el vergel florido, al que hace danzar, como vimos, de júbilo ultra terreno.

Importa insistir que este soto que danza en rapto místico al son del canto primaveral del ruiseñor es un soto nocturno. No puede no serlo, ya que el ruiseñor canta de noche, y lo sabe San Juan, que pasa a celebrar en su próximo verso precisamente a "la noche serena", otro de los dones nupciales del Amado. Un sufí entendido en la literatura en clave de los iniciados comprendería 
inmediatamente que la "noche serena" constituye otro tópico místico más, ya que el espacio nocturno es un hito en el camino hacia la Trascendencia. Tanto Miguel Asín Palacios como yo hemos dedicado largas páginas al Leitmotiv nocturno, que es un símbolo místico curiosamente plurivalente tanto para el poeta de Fontiveros como para los místicos del Islam. Para ambos la noche apunta a la purgación del alma -la sequedad purgativa y la tristeza-pero, simultáneamente, alude al momento extático jubiloso en el que se anochecen los sentidos y la razón para que pueda surgir la luz interior en el hondón último del alma, ya desasido de lo material. Veremos pues que la noche se sufre como oblación en la senda mística y a la vez se celebra como el momento culminante del éxtasis. Pero aquí estamos festejando unas bodas, la misma que celebró en el siglo XII Rūmī en apasionados versos: "Hacia la noche de mi corazón / por una senda estrecha / anduve a tientas / y he aquí que de repente surge la luz / y la infinita tierra del día" (Arberry 1968: 117). Abū al-Māwāhib al-Šadilī también exclama extático en sus Máximas de la iluminación: ¡Oh noche de amor y de felicidad! ¡Su alegría hizo a nuestros briosos corceles danzar de gozo! La oscuridad no es nociva para el espíritu perfecto..." (Jurgi 1938: 59). Šabastarī, en su famosa Rosaleda secreta, más cerca aun del santo carmelita, celebra el aspecto jubiloso de la noche en un verso célebre para todo sufí: "Noche luminosa, mediodía oscuro" (Corbin, L'homme de lumière 117). Imposible no recordar la noche de San Juan, "más clara que la luz del mediodía". Otro tanto esta noche serena que sirve de escenario feliz al canto del ruiseñor. La noche espiritual de esta lira celebra pues un momento de alegría extática, pues los períodos ascéticos han quedado atrás. La oscuridad serena aniquila nuestros sentidos y nuestra razón para dar paso a la vivencia gozosa de la iluminación, que pasa a ser celebrada, como consecuencia, en el último verso: "con llama que consume y no da pena".

Esta llama transformante es afín a todas las tradiciones místicas: de seguro con la sola mención de la "noche" y la "llama", la Madre Ana de Jesús quedaría alertada al hecho de que su poeta barajaba abreviaturas metafóricas para el éxtasis místico. No en balde el Reformador habría de dedicar dos poemas futuros a ambos motivos temáticos: la "Noche" y la "Llama". Los dos símbolos parecen ser parte del regalo sin par-del innombrable "aquello" que su Amado le dio en el instante sagrado a salvo del tiempo que la esposa denomina como "el otro día". Los sufíes, como he tenido ocasión de explorar en estudios previos, también supieron de esas conflagraciones de jardines místicos asociadas justamente al canto del ruiseñor. 
El símil de la llama, que consume no solo al ruiseñor, sino al mismísimo jardín danzante y nocturno en el que canta de gozo, tampoco escapó a los místicos musulmanes. Esta extraña imagen de "la llama que consume y no da pena" que irrumpe en el jardín místico y que pone broche al alucinado torrente verbal de la lira embriagada, la reconocerían gnósticos como Ibn al-'Arabī, quien inaugura la estrofa más famosa de su Tarŷumān al-ašwāq (Intérprete de los deseos) justamente con la llama transformante en medio de un vergel: "¡Oh maravilla! Un jardín entre llamas”. La idea resulta clara para un sufí: el corazón profundo o qalb, sede de la gnosis mística, queda representado bajo la imagen de un jardín o huerto divinal que queda envuelto en llamas porque se encuentra en estado de perpetua transformación (La voz taqallub, una de las variantes de la raíz trilítera $q-l-b$ significa precisamente eso: "transformarse"). El fuego convierte en sí todo lo que toca, y por eso este corazón/jardín u hondón del alma del místico es capaz de dejarse "quemar", es decir, de convertirse por participación en todas las manifestaciones de Dios simultáneamente sin atarse a ninguna, porque se incendia en todas. Lo glosa a su modo el propio San Juan en sus Dichos de luz y amor: "Lo que pretende Dios es hacernos dioses por participación, siéndolo Él por naturaleza. Como el fuego convierte todas las cosas en fuego" (Dicho 106).

El alma que llega a este grado místico sublime se encuentra, según Michael Sells, "in the station of no station" (maqām lā maqām)-es decir, en la "morada de la no-morada-". El contemplativo ha alcanzado una morada mística tan alta que ya no se tiene que apegar a ninguna otra, por beneficiosa que sea: todas las recibe jubiloso. La sucesión hipnótica de imágenes que constituye la lira parecería indicarnos que éstas no terminan nunca: da la impresión de que se nos derriten ante los ojos, como las imágenes que R¥m• celebraba ver desleídas en su Fīhi mä fìhi, cual hielo invernal ante el calor de la primavera del espíritu. Y es que hemos acabado por abrasarnos en todas las imágenes, sin excepción, en el afortunado locus a-temporal y a-espacial del alma transformada en Dios. O transformándose perpetuamente en Dios: es difícil medir el tiempo cuando éste ha sido borrado.

Salta a la vista que San Juan ha logrado crear el único ruiseñor feliz de las letras occidentales. Ante todo lo que venimos explorando, no parecería exagerado considerar que el canto de este ruiseñor juancruciano "extranjerizante" se asemeja más a la melodía exaltada del bolbol de los persas que a la triste cantinela de la filomena de las Geórgicas de Virgilio. La contextualidad sufí, aparentemente más alejada históricamente de la clásica para este poeta egresado de la cultísima Salamanca, resulta, sin embargo, particularmente 
fértil a la hora de decodificar los secretos de la rara avis del "Cántico". Acaso la Madre Ana de Jesús se encontraba a salvo, culturalmente hablando, de la espesa tradición virgiliana y supo decodificar sin mayor problema la filomena sanjuanística como ave del éxtasis. No descuento, una vez más, que símiles como éstos se encontraran lexicalizados y fueran muy conocidos en los ambientes monacales es donde se generaron y se leyeron los versos del santo. Posiblemente nuestra cultura clásica nos ha dificultado el acceso a algunos símbolos cruciales de San Juan, que acaso sus primeros lectores comprendieran sin tanto esfuerzo erudito de confrontación de fuentes antiguas.

\section{B. EL PÁJARO SOLITARIO}

San Juan concibe al alma como "pájaro solitario" (tal el "passer solitarius" del salmo 101:8 de David) tanto en los Avisos espirituales o Dichos de luz y Amor (también llamados Puntos de amor), como en las glosas al "Cántico" (CB 14,24). En algún otro pasaje adicional el poeta comentarista aludirá también, aunque brevemente, a la imagen del pájaro de su alma, tal como lo hace en el capítulo 14, 11 del Libro II de la Subida. El Tratado de las propiedades del pájaro solitario, que tanto nos hubiera iluminado, está, hasta el presente, perdido. Es una verdadera lástima, pues al ser un tratado extenso, nos hubiéramos podido hacer una idea precisa de las modalidades de esta ave juancruciana, que resulta extrañísima a la luz de las pasajes en torno a ella que han llegado hasta nosotros.

La versión más larga que poseemos de la imagen del pájaro solitario es, al menos hasta ahora, la incluida en las glosas al "Cántico", de la que el esquema de los Dichos no es sino un apretado resumen. A San Juan debió serle muy familiar el motivo simbólico, ya que, pese a las diferencias en extensión, ambas versiones son prácticamente las mismas. He aquí el texto más completo:

Este conocimiento [de la divina luz] entiendo quiso dar a entender David cuando dijo: Vigilavi, et factus sum sicut passer solitarius in texto; que quiere decir: Recordé y fui hecho semejante al pájaro solitario en el tejado (Ps 101, 8). Como si dijera: abrí los ojos de mi entendimiento y halléme sobre todas las inteligencias naturales, solitario sin ellas en el tejado que es sobre todas las cosas de abajo. 
Y dice aquí que fue hecho semejante al pájaro solitario, porque en esta manera de contemplación tiene el espíritu las propiedades desde pájaro, que son cinco: la primera, que ordinariamente se pone en lo más alto; y así el espíritu, en este paso, se pone en altísima contemplación. La segunda, que siempre tiene vuelto el pico donde viene el aire; y así el espíritu vuelve aquí el pico de afecto hacia donde viene el espíritu del amor, que es Dios. La tercera es que ordinariamente está solo y no consiente otra ave alguna junto a sí, sino que, en posándose alguna junto, luego se va; y así el espíritu en esta contemplación está en soledad de todas las cosas, desnudo de todas ellas, ni consiente en sí otra cosa que soledad en Dios. La cuarta propiedad es que canta muy suavemente, y lo mismo hace a Dios el espíritu en este tiempo, porque las alabanzas que hace a Dios son de suavísimo amor, sabrosísimas para sí y preciosísimas para Dios. La quinta es que no es de ningún determinado color; y así es el espíritu perfecto, que no solo en este exceso no tiene algún color de afecto sensual y amor propio, mas ni aun particular consideración en lo superior e inferior, ni podrá decir dello modo ni manera, porque es abismo de noticia de Dios la que posee, según se ha dicho. (CB 14, 24)

El punto de arranque de la inspiración del Senequita de Santa Teresa no puede ser más claro: su pájaro es "solitario" como el passer solitarius del salmo 101, 8 de David. Pero aquí terminan nuestras claves. Las "condiciones" o "propiedades" que San Juan adjudica a continuación al ave de su alma extática no parecen tener un antecedente claro en la tradición literario-mística occidental. Estas propiedades enigmáticas convierten el pájaro solitario de San Juan en un símbolo que ha atormentado a estudiosos como el P. Eulogio Pacho por su total carencia de antecedentes occidentales. Hay que decir enseguida que la alegoría de la equivalencia del alma como pájaro es tan universal que no ofrece mayores problemas filogenéticos. Ya la tenemos documentada en el antiguo Egipto, y Platón, siglos más tarde, volverá a insistir en ella en su Fedro, advirtiendo los estrechos paralelos entre el alma en vuelo hacia las regiones etéreas y las criaturas aladas. Hasta en los psalteiros maniqueos encontramos el símbolo del espíritu como pájaro: todas las religiones principales lo han hecho suyo. Pero los pormenores del pájaro solitario juancruciano en realidad son muy difíciles de encontrar en Europa: cuando revisamos a San Buenaventura, a San Bernardo, a Hugo de San Victor, a Lulio, el Beato Orozco, a Laredo, o bien textos anónimos medievales como el Libro das aves portugués y el Ancren Riwle (The Nun's Rule), de una anacoreta inglesa del 
siglo XIII, nos es fuerza admitir que no nos son útiles a la hora de entender las claves ornitológicas de San Juan.

Es una tarea verdaderamente desalentadora buscar paralelos importantes entre San Juan y estos autores ascético-místicos que le precedieron o que fueron sus contemporáneos. Gaston Etchegoyen explora el símbolo del pájaro espiritual en su libro póstumo L'amour divin. Essai sous les sources de Sainte Thérèse (1923) y aunque, para sorpresa del lector, excluye de su estudio a San Juan, sí rastrea el uso del símil del ave espiritual en autores como Raimundo Lulio, santa Teresa, Francisco de Osuna (Tercer abecedario espiritual), Alonso de Orozco (Vergel de la oración) y Bernardino de Laredo (Subida del Monte Sión). Hay que decir, sin embargo, que en todos estos casos estamos lejos de las elaboraciones alegóricas del Reformador.

Cuando tendemos nuestra mirada a la poesía tradicional en lengua española, tampoco encontramos antecedentes al pájaro alegórico sanjuanístico. En su minucioso estudio Las aves en la poesía castellana, Salvador Novo traza el tema del ave en la poesía en lengua española desde la Edad Media hasta la literatura hispanoamericana contemporánea, pero omite del todo el pájaro solitario del santo. Tampoco menciona ninguna alegoría mística que guarde relación con las propiedades que definen el ave mística de San Juan.

No es de extrañar que el Islam, como todas las religiones del mundo, sacase provecho de la imagen universal del pájaro-alma. Ya tuve ocasión de citar el famoso versículo del Corán en el que las palabras de Salomón celebra haber entrado en posesión del "lenguaje de los pájaros", el mismo que Naŷm ad-dīn al-Kubrā reclamó para sí: "La alabanza a Dios, que nos dio el lenguaje de los pájaros". A lo largo de la Edad Media, ya lo sabemos, los tratados musulmanes sobre el pájaro místico se suceden -Sanā'ī, 'Aț̣āar, Bāyazīd al-Bisțāmī- constituyendo lo que Henry Corbin, como adelanté, llamaba el "cycle de l'oiseau".

Detengámonos en las "propiedades" del pájaro sanjuanístico porque, una vez más, las claves más fecundas del Reformador parecen ser sufíes. Los pormenores concretos a que tanto los místicos del Islam como San Juan acuden para elaborar dicho símbolo tiene paralelos inquietantes. En más de una ocasión, como veremos, la coincidencia es tan exacta que nos plantea un verdadero problema de filiación literaria. El santo coincide estrechamente con el persa Al-Bisțāmī (m. 877), que se autodescribe como "un pájaro cuyo cuerpo estaba constituido por la Unidad", y que vuela "en singularidad" (“Aț̣ār 1966, s.p.). Recordemos a San Juan: su pájaro es "solitario" y no sufre "compañía" de otra criatura" (Puntos de amor 41). El pájaro simbólico de 
Rūmī vuela alejándose de todo lo material y perecedero (Nicholson 1945: 86); el de San Juan "ha de subir sobre todas las cosas transitorias" (Puntos de amor 41).). El ave del persa levanta su cabeza hacia Dios ('Atțār 1966, s.p.), el del carmelita "el pico al aire del Espíritu Santo" (Puntos de amor 41). Hallāŷ exclama en su Kitāb al-Tawāsinn "vuelo con mis alas hacia mi Amado" (34), mientras que en el vuelo de San Juan, "El espíritu" [...] se pone en altísima contemplación" (CB 14, 24). Y ambos terminan por adquirir un conocimiento que trasciende toda razón: el alma de Hallâŷ, como ave metafórica, "cayó en el mar del Entendimiento y se anegó en él” (1974: 34); la de San Juan se eleva tanto que "queda como ignorante de todas las cosas, porque solamente sabe a Dios sin saber cómo" (S II: 14, 11).

Pero la coincidencia más interesante la tiene San Juan con el pájaro contemplativo de Suhrawardī. Recordemos que en sus breves escorzos del ave del alma, San Juan nos presenta un pájaro simbólico cuyo vuelo apenas se describe: solo sabemos que "pone en lo más alto" y que tiene cinco propiedades particulares, algunas de ellas bastante enigmáticas. Da pues la impresión de ser un ave no solo extática, sino además estática, y en esto se aleja de los pájaros voladores de otros contemplativos musulmanes. Esto mismo, sin embargo, va a acercar a San Juan al citado Suhrawardī, que fue un místico muy conocido dentro de la tradición literaria sufí. Suhrawardī o Sihāb al-Dīn Yaḥhyā ibn Ḥabas ibn Amīrak al-Suhrawardī, nacido hacia 1153 en Suhraward en Persia, fue conocido como al-Maqtūl (el "asesinado" o "ejecutado"), porque fue condenado a muerte por hereje bajo Malik uzZāhir en 1191. Suhrawardī está considerado como el Šeyj al-išrāq (maestro de la filosofía de la iluminación") gracias a su abundante literatura sobre el tema: escribió cerca de cincuenta libros en árabe y en persa, influidos por Avicena, por el helenismo y por importantes elementos iraníes y orientales antiguos, entre los que cabe recordar su Hikmāt al-išrāa (La filosofía de la iluminación) y su Hayāqil an-nūr (Los altares de la luz). Sus seguidores insisten tanto en esta luz interior que adquirieron el nombre de "iluminados" o "alumbrados", como aquella secta perseguida del XVI español.

Pero lo que nos interesa aquí es lo que Suhrawardī tiene que decir sobre el pájaro místico de su alma. Es precisamente una de sus imágenes favoritas, que parece deber mucho a las enseñanzas de Avicena, ya que uno de sus tratados ornitológicos constituye prácticamente una traducción del Risalāt al-Ṭair del gran filósofo. Así parece insinuarlo el título mismo de su opúsculo ornitológico: Tarŷumā lisān ul-ḥaqq wa-huwa Risalāt ut-Ṭair (Traducción del lenguaje de la verdad, y éste es el tratado del pájaro). 
En este opúsculo, como dejé dicho, el pájaro o Simurg de Suhrawardī no se nos ofrece en pleno vuelo, sino que aparece descrito sobre la base de sus "propiedades" o características místicas. El Simurg o pájaro místico, como era de esperar, "representa al sufí (sālik) que ha superado todas las moradas (maqāmāt) del camino(țarīqa) y ha llegado a la meta (fanā fìl-haqq) (Spies 6). Si eliminamos la terminología técnica sufí, estamos ante el meollo del símbolo sanjuanístico: el pájaro representa su alma, que ya ha alcanzado los niveles más altos del éxtasis. Sorprendentemente, este remoto alegorista del siglo XII va a preludiar casi todas las "condiciones" del ave de San Juan, incluso la más rebuscada: no tiene determinado color. Como vimos, algunas de las propiedades del ave mística parecen constituir ya imágenes tradicionales -incluso lugares comunes codificados de la tradición literaria musulmana- y por eso ya he citado a otros tratadistas y poetas sufíes con quienes el Reformador $-\mathrm{y}$ también, naturalmente, Suhrawardī- coinciden de cerca en cuanto a las propiedades del ave mística.

No hay duda de que la quinta propiedad del pájaro solitario de San Juan es la que resulta más extraña: "no ha de tener determinado color" (Avisos espirituales / Puntos de amor 41). Explica el santo "así es el espíritu perfecto [...] (CB 14, 24), que no tiene "determinación en ninguna cosa (Avisos espirituales / Puntos de amor 41). Curiosa imagen la del pájaro incoloro. Asombra constatar que Suhrawardī la había articulado en idéntico sentido para referirse a su propio Simurg cuatro siglos antes que el Reformador: "todos los colores están en él, pero no tiene determinado color" (Nasr 1964: 30). En ambos casos, por más, lo incoloro implica el desasimiento y vacío de todo lo material en el alma.

Vale la pena recordar que esta imagen espiritual de lo incoloro no ha resultado ajena a otros místicos del Islam. Seyyed Hossein Nasr advierte que también 'Atțāa alude a la ausencia de color en el Simurg en su célebre Manțīq al-țayr. Cuando los treinta pájaros (si-murg), cada uno de distinto color, descubren, en el umbral mismo del éxtasis, que ellos eran el Simurg o "Pájaro-Rey" que tanto buscaban, se anula el hermoso arcoíris de sus diversos colores, por lo que tampoco tienen, en éxtasis transformante, "determinado color". Se trata de un lugar común de la literatura mística persa: también Hāfiz alude, en uno de sus versos más hermosos, al desasimiento espiritual a través del desasimiento de los colores ("soy esclavo de la voluntad de aquel que bajo la esfera azul ha quedado libre de todo aquello que posee determinado 
color"5). Repetirá la imagen, con variantes, el citado al-Kubrā en su Fawāt'ịh

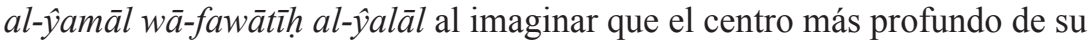
alma (qalb) es incoloro y fluctuante como el agua y resulta capaz, por ello mismo, de reflejar el infinito. Es tan cara la imagen de la ausencia de color determinado (que implica, obviamente, la posesión simultánea de todos los colores), que el poeta andalusí Abū-l-Ḥasan al-Šuštarī (s. XIII) celebra a Lāyla, la legendaria amada de Maŷnūn y símbolo del Dios infinito, con la imagen de un ojo carente de color determinado, pero poseedor de todos los colores: "Ella es como el ojo que no tiene color / pero que contiene colores de todos los matices" (al-Šuštarī 2009: 54).

Las coincidencias de San Juan con la condición incolora y a la vez capaz de incluir todos los colores de su ave mística, muy propias de los sufíes, son pues asombrosamente estrechas. El enigmático pájaro juancruciano, que es solitario, que se va a lo más alto, que pone el pico al aire, que canta con suavidad y que carece de determinado color coincide con cada una de las propiedades del Simurg de los musulmanes y muy poco tiene que ver con los pájaros literarios de la Antigüedad clásica. Ni siquiera, como vimos, responde a las aves espirituales de los espirituales peninsulares. Por eso no cabe sino lamentar una vez más la pérdida del exhaustivo tratado de San Juan sobre el pájaro solitario, que tantas claves adicionales nos hubiera podido ofrecer.

Salta a la vista, pues, que San Juan maneja una ornitología mística sin parangón en las letras occidentales: un oximorónico ruiseñor gozoso y un pájaro solitario inexplicablemente incoloro. Asombra considerar que un lector versado en la simbología mística musulmana es capaz de comprender inmediatamente lo que el poeta de Fontiveros quiso realmente decir a sus lectores conventuales.

\section{BIBLIOGRAFÍA}

Arberry, Arthur J. Sufism. An Account of the Mystics of Islam. London: George Allen \& Unwin Ltd., 1968.

al-Hallāŷ, Mansūr. The Tawasin. The Great Sufi Text on the Unity of Reality. Trad. Aisha Abd ar-Rahman al-Tarjumana. Berkeley y Londony: Diwan Press, 1974.

$5 \quad$ Agradezco a mi querido amigo Seyyed Hossein Nasr que me tradujera del persa el pasaje, que yo a mi vez vierto al español. 
al-Kubrā, Nagm ad-Din. Fawāt' iḥ al-gamāl wā-fawātīh al-galāl. Akademie der Wissenschaften und der Literatur, Ed. Fritz Meier. Wiesbaden: Veröffentlichungen der Orientalischen Kommision, Bd. IX, 1957.

al-Šuštarī, Abū-1-Ḥasan. Sons of Love and Devotion. Trad. y Ed. Lourdes Álvarez. New York/ Mahwah: Paulist Press, 2009.

'Attar, Farid ad-din. Muslim Saints \& Mystics. Episodes from the Tadhkirat al-Auliya'(Memorial of the Saints). Trad. Arthur J. Arberry. Londres: Routledge \& Kegan Paul, 1966.

Bakhtiar, Laleh. Sufi. Expressions of the Mystic Quest. London: Thames \& Hudson, 1976.

Borges, Jorge Luis. Obras completas. 4 Vols. Buenos Aires: Emecé Editores, 1989.

Corbin, Henri. Trilogie Ismalienne, Teheran-Paris, 1961.

L'homme de lumière dans le soufisme iranien. Paris: Ed. Présence, 1961a.

Etchegoyen, Gaston. L'amour divin. Essai sous les sources de Sainte Thérèse. Bourdeaux/ Paris: Feret \& Fils Éditeurs, 1923.

Ibn al- 'Arabī, Muhyi'dīn. (1911/1977). The Tarjumān al-Ashwāq. A Collection of Mystical Odes. Bilingual Edition. R. A. Nicholson, tr. London: Royal Asiatic Society, 1911; London: Theosophical Publishing House, Ltd., 1977. Traducción española: Carlos Varona Narvión, Murcia: Editorial Regional de Murcia, 2002 y Vicente Cantarino: México, Porrúa, 1977; traducción francesa: Maurice Gloton: Paris, Albin Michel, 1996.

Ibn al-Faridh, 'Omar (1932). L'Éloge du vin (Al Khamriya, Poème mystique). Ed. de Émile Dermenghem. Paris: Les Éditions Véga. Traducción española: Carlos Varona Narvión Madrid: Hiperión, 1989.

Juan de La Cruz, San. Obra Completa. 2 vols. Madrid: Alianza, 1991/2015.

Jurgi, Edward Jabra. Ilumination in Islamic Mysticism. Princeton: Princeton University Press, 1938.

Lederer, Florence, ed. The Secret Rose Garden of Sa'd ud-din Mahmud Shabistari. Lahore, 1969.

López-Baralt, Luce. "Simbología mística musulmana en San Juan de la Cruz y en Santa Teresa de Jesús”. Nueva Revista de Filología Hispánica XXX (1981): 21-91.

Huellas del Islam en la literatura española. De Juan Ruiz a Juan Goytisolo. Madrid: Hiperión, 1985/1989.

San Juan de la Cruz y el Islam. Colegio de México / Universidad de Puerto Rico. Madrid: Hiperión, 1985/1990.

Estudio introductorio. Šadilies y alumbrados de Miguel Asín Palacios. Madrid: Hiperión, IX-LXVII, 1990.

"La visio smaragdina de San Juan de la Cruz: acerca de las esmeraldas trascendidas que encontró en el fondo de su alma iluminada". Nueva Revista de Filología Hispánica, México, (1997): 68-99.

Asedios a lo indecible. San Juan de la Cruz canta al éxtasis transformante. Madrid: Trotta, 1998.

Estudio introductorio y traducción del árabe. Moradas de los corazones de Abūl-Hasan Al-Nūrī de Bagdad. Madrid: Trotta, 1999. 
The Sufi Trobar Clus and Spanish Mysticism. A Shared Symbology. Lahore. Pakistan: Iqbal Academy.

"Santa Teresa y el Islam: nuevos hallazgos en torno al símil de los siete castillos concéntricos del alma". Mujeres de Luz. Congreso Internacional Sobre Mística Femenina. Pablo Beneito, ed. Madrid: Editorial Trotta (2001a): 53-76.

"La amada nocturna de San Juan de la Cruz se pudo haber llamado Laylā". Mujeres de luz. Congreso Internacional sobre mística femenina, Pablo Beneito. Ed. Madrid: Editorial Trotta, (2001b): 235-266.

"El corazón simbólico en San Juan de la Cruz, espejo de la manifestación infinita de Dios en vertiginoso cambio perpetuo". María Pilar Manero. Ed. Literatura y espiritualidad. Bacelona: Universitat de Barcelona (2004): 121-154.

A zaga de tu huella: La enseñanza de las lenguas semíticas en Salamanca en tiempos de san Juan de la Cruz. Madrid: Trotta, 2006. 2009.

"San Juan de la Cruz y el Islam". Diccionario Carmelita de Espiritualidad. Burgos,

"Acerca del aroma del Yemen en la literatura española y de la dificultad de su estudio". Actas de la Asociación Internacional de Hispanistas. Patricia Botta. Ed. Rumbos del hispanismo en el umbral del cincuentenario de la AIH. Roma: Bagatto Libri, 2012.

"La filomena de San Juan de la Cruz, ruiseñor de Virgilio o de los persas?". SUFI. Madrid: Editorial Nur, 2012a.

"Ultra Auroram et Gangem. Islamic Themes in Jorge Luis Borges". Cambridge Companion to Borges. Edwin Williamson. Ed. Cambridge, England: Cambridge University Press (2014): 68-80.

y Eulogio Pacho, eds. San Juan de la Cruz. Obra Completa. 2 vols. Madrid: Alianza, 1991/2015.

Massignon, Louis. La passion de Hallâj, 4 vols. Paris: Gallimard, 1975.

Nasr, Seyyed Hossein. Three Muslim Sages: Avicenna, Suhrawardi, Ibn 'Arabî. Cambridge: Harvard University Press, 1964.

Nicholson, A. R. Poetas y místicos del Islam, traducción y estudio preliminar de Fernando Valera, México, 1945.

Novo, Salvador. Las aves en la poesía castellana. México: Fondo de Cultura Económica, 1953.

Nurbakhsh, Javad (1983-1991). Sufi Symbolism. (Translation from the Farhang-e Nurbakhsh. The Nurbakhsh Enciclopedia of Sufi Terminology). Five Vols. London/New York: Khanikahi-Nimatullahi Publications. (Existe una edición posterior inglesa de 1990 en 16 volúmenes, y una edición española, Simbolismo sufi, publicada por la Editorial Nur de Madrid en 2003-2010).

Schimmel, Annemarie. Mystical Dimensions of Islam. Chapel Hill: The University of North Carolina Press, 1975.

The Triumphal Sun. A Study of the Works of Jalaloddin Rumi. London and The Hague: East-West Publications, 1980. 
Sells, Michael. "Ibn 'Arabī’s Garden Among the Flames: The Heart Receptive of Every Form”. Mystical Languages of Unsaying. Chicago and London: The University of Chicago Press, (1994): 90-115.

Smith, Margaret. The Sufi Path of Love. An Anthology of Sufism. London: Luzac \& Co., 1954.

Spies, Otto and Khatar, S. K., eds. and transl. Three Treatises on Mystics by Shihabuddin Suhrawardi Maqtul. Khatak, 1935. 